\title{
Entre as almas e as câmeras: Arqueogenealogias do corpo indígena
}

\author{
Between spirits and cameras: Archeogenealogies of the native body
}

\author{
Maurício NEVES-CORRÊA \\ Universidade Federal do Amapá (Unifap)
}

https://orcid.org/0000-0002-4865-3364

\begin{abstract}
RESUMO: O objetivo deste artigo é analisar os limites éticos e estéticos das histórias filmadas sobre corpos indígenas. Nossa proposta é analisar a partir dos estudos de Michel Foucault, a não-imagem de indígenas isolados, além de dois vídeos sobre a questão da relação do trabalho e dos povos indígenas. Essas produções de temporalidades diferentes, postadas na WEB, se ligam e se desligam ao passado e ao presente a partir das teias do discurso. Nesse sentido, o que buscamos são as inscrições da história no corpo que emerge nesses outros espaços digitais. Através da arqueologia como método e da genealogia como atitude, a ideia é reativar fragmentos de lutas dos povos nativos, para empreender uma crítica do presente.
\end{abstract}

PALAVRAS-CHAVE: 1.Corpos Indígenas 2. Histórias Filmadas 3. Arqueogenealogia.

ABSTRACT:The purpose of this article is to analyze the ethical and aesthetic limits of the stories filmed about native bodies. Our proposal is to analyze, based on Michel Foucault's studies, the non-image of isolated indigenous people, as well as two videos on the issue of the relationship between work and indigenous peoples. These productions of different temporalities, posted on the WEB, connect and disconnect to the past and the present from the webs of discourse. In this sense, what we are looking for is the inscriptions of history on the body that emerges in these other digital spaces. Through archeology as a method and genealogy as an attitude, the idea is to reactivate fragments of struggles of native peoples, to undertake a critique of the present.

KEYWORDS: Native bodies; Filmed Stories; Archeogenealogy.

\section{O roubo das almas: uma introdução}

\author{
Os xabori estão descobrindo que máquina, \\ câmera estão destruindo a nossa imagem, vocês \\ falam imagem... \\ Davi Kopenawa Yanomami
}

A luz que reflete em nossos corpos é apreendida, capturada, enquadrada por filmadoras e câmeras. Para o cineasta Francês Jean-Luc Godard, "Fotografia é verdade. Cinema é verdade vinte quatro vezes por segundo". Vivemos numa época em que estas verdades ocupam um papel central na história do presente. Aparelhos se proliferam por 
todos os lados, dos tetos das construções aos nossos bolsos, sob o olhar das câmeras: nossas selfies, dores e amores. Nossa sociedade tornou-se espelhada por essas luzes que brilham em telas espalhadas por todos os cantos. Agora, as telas de cinemas se espalharam por todos os nossos espaços e tornaram complexos os regimes de governamentalidade.

No palco das imagens, atualmente, batalhamos pelas subjetividades que atravessam nossos corpos, as identidades recolhidas sob a luz dos filmes, reportagens, vídeos. A epígrafe acima foi retirada de uma entrevista ${ }^{1}$ de Davi Kopenawa Yanomami, um xamã do povo Yanomami e uma das principais lideranças indígenas do Brasil. Ao ser questionado pelos entrevistadores sobre a relação de seu povo com os vídeos e as fotos, ele revela que, segundo os espíritos, os Xarobi ${ }^{2}$, as câmeras estariam por destruir suas imagens. A partir deste relato, sugiram muitas questões sobre como a reprodução de nossas imagens e palavras afetam e fazem aquilo que somos. Kopenawa nos mostra um choque entre a cosmologia Yanomami e a produção imagética e fílmica.

Ainda sobre este assunto, outra notícia nos chamou atenção, uma reportagem ${ }^{3}$ veiculada pelo portal G1, que relata a alta abstenção de indígenas na eleição de 2010. Isto ocorreria porque a maioria dos indígenas não possuíra documento com foto. Os Yanomami, segundo a reportagem, recusavam-se a obter esses documentos, pois as fotos lhes roubariam suas almas. Isto nos fez refletir sobre uma invasão da imagem e do vídeo que se prolifera em nossa sociedade, das verdades que essas produções fílmicas e fotográficas criam e dos embates, choques, entre o sujeito e o poder, pois: "Somos submetidos pelo poder à produção da verdade e só podemos exercê-lo através da produção da verdade" (FOUCAULT, 2007, p.101).

As verdades têm como alvo o corpo do sujeito, essa jaula que nos aprisiona a alma, como diz Foucault (2007). Daí este, talvez, seja o motivo pelo qual o corpo se torna o objeto preferencial, que desperta o fascínio das imagens. Isto, quem sabe,

\footnotetext{
1 Entrevista concedia ao programa Rodada viva da TV Cultura Paulista. Disponível em: http://www.rodaviva.fapesp.br/materia/42/entrevistados/davi_yanomami_1998.htm. Acessado em 13 de abril de 2017

${ }^{2}$ Espírito que protege, espírito que anda em qualquer lugar. Espírito que qualquer gente que usa como rezar. Então, nós chama "xamã", "xapïribë". (Davi Kopenawa Yanomami) Entrevista concedia ao programa Rodada viva da TV Cultura Paulista. Disponível em: http://www.rodaviva.fapesp.br/materia/42/entrevistados/davi yanomami 1998.htm. Acessado em 13 de abril de 2017

${ }^{3}$ Sem documento com foto, abstenção de índios na eleição pode ser grande. Disponível em: http://g1.globo.com/especiais/eleicoes-2010/noticia/2010/10/sem-documento-com-foto-abstencao-devotos-de-indios-pode-ser-grande.html. Acessado dia 19/04/2017
} 
explique o motivo das câmeras, atualmente, se situarem na parte da frente dos aparelhos celulares e reivindicarem o lugar dos espelhos, o poder de capturar nossa luz e voz, aprisionar o tempo por breves instantes e nos formatar em quadros e retângulos.

Outro aspecto decisivo nesse processo é a internet. O mar de bits que materializa e faz circular todas essas luzes, todos esses corpos. O lugar da materialidade virtual reverbera em nossos corpos e é o mar para onde os filmes, as palavras, as fotos e as músicas têm convergido. Lá, essas entrevistas e reportagens persistem e chegam até nós, deslocadas de seu tempo. Reveladas por oráculos coloridos, adornados de palavras cintilantes, sempre dispostos a nos ajudar em troca de nossas perguntas, localizações, preferências. Sempre prontos a dar um perfil de nossos corações à publicidade daquilo que acham que queremos.

A partir destes acontecimentos que se ligam e saltam sob os nossos olhos como uma teia, somos paralisados pelo veneno da aranha e nos sentimos forçados a pousar nosso olhar sob estes temas. Em função disso, levantaremos algumas questões, que pretendemos nos dar como problema nesse trabalho:

a) Em primeiro lugar, procurarmos ver os limites éticos e estéticos das imagens fílmicas e nos propomos a analisar a não-imagem de um vídeo de indígenas isolados no acre. Neste primeiro momento, também discorremos sobre o método Arqueogenealógico proposto por Michel Foucault através de uma crítica do presente;

b) No segundo momento, procuraremos entender como o corpo se efetiva nesses outros espaços de virtualidade digital inscritas em tecnologias moveis, lugares de utopia efetivamente realizada, nessas heterotopias. Qual a relação da WEB com as imagens, os sons, as vozes, o discurso e o corpo. Tomaremos como referência o estudo apresentado no texto, Discursos $e$ imagens do corpo: heterotopias da (in)visibilidade na web, de Rosário Gregolin (2015a), que atualiza o conceito de heterotopia de Michel Foucault e mostra a WEB como heterotopia por excelência da atualidade;

c) Por fim, analisaremos dois vídeos indígenas de temporalidades diferentes, postados na WEB, mas que se ligam e se desligam ao passado e ao presente a partir das teias do discurso.

A perspectiva das fraturas cosmológicas vividas pelos Yanomami com as câmeras e as suas almas será partilhada também na análise de histórias filmadas sobre sujeitos indígenas. O nosso olhar se volta para estas questões por serem pontos sensíveis 
da história do presente de nossa sociedade, por representar um choque com o poder, pequenos pontos em que saberes subterrâneos emergem de sua margem, em acontecimentos que deixaram os discursos como indícios de sua existência. São desventuras dispersas que se ligam umas às outras por uma rede combatível, inteligível, genealógica, por entre suas cinzas esvoaçantes. São essas antologias de poemas-vidas que pretendemos reativar, por meio de uma rede, umas às outras, em nosso trabalho.

\section{O réquiem dos corpos isolados e a Arqueogenealogia como crítica do presente}

Houve, em certa ocasião, um vídeo postado no YouTube, que circulou por diversas espaços na própria internet e até mereceu algumas reportagens em telejornais, que retratava a primeira história filmada de um povo indígena isolado. Eles vivem em algum lugar entre a Amazônia brasileira e a Amazônia peruana e nossa primeira intenção foi analisar tal narrativa, porém algo não nos parecia ético neste vídeo. Apesar de termos capturado um frame, para em seguida apagá-lo, percebemos que havia algo aterrorizador. Por fim, resolvemos assumir este apagamento e nos centramos nos motivos deste silenciamento, como veremos mais a seguir.

Em primeiro lugar, no rastro do que propõe Foucault (2008a), tomando as imagens como documentos, sem dificuldade, é possível considerar o vídeo sobre os índios isolados como documentos infames. Sabemos que estes documentos podem ser o único registro de uma vida, um parágrafo que registra as únicas palavras desafortunadas da existência de alguém, um efêmero fotograma que inscreve um indivíduo na memória visual do Ocidente. Um criminoso, um louco, alguém que outrora se desviou da norma e entrou num choque fatal com o poder, quem sabe um indígena ou um grupo deles.

Michel Foucault, em "A vida dos homens Infames" (2003), mostra de forma didática e poética, como selecionou uma série de relatos sobre sujeitos em seus infortúnios com o poder. Quando selecionamos histórias filmadas sobre os povos indígenas, seguindo neste caminho, sem dúvida, estamos preocupados em remexer esses saberes dominados e causar pequenas fissuras no julgamento definitivo de suas identidades diante dos olhos tão complexos de nossa sociedade, hoje.

Eu quis que se tratasse sempre de existências reais; que se pudessem dar-lhes um lugar e uma data; que por trás desses nomes que não dizem mais nada, por trás dessas palavras rápidas e que bem podem ser, na maioria das vezes, falsas, mentirosas, injustas, exageradas, houvesse homens que viveram e estão mortos, sofrimentos, malvadezas, ciúmes, vociferações (FOUCAULT, 2003, p.204). 
Analisar os discursos na emergência de seus acontecimentos pode nos deixar um tanto míopes. Por este motivo, talvez Michel Foucault tenha preferido analisar acontecimentos em durações mais longas. Provavelmente, por isso ele tenha desenvolvido suas pesquisas, sempre preocupado com uma história que emerge do presente, mas sem se voltar apenas para ele. Ele nos deixou as ferramentas necessárias para prosseguirmos com sua teoria rumo ao século XXI e antecipou pesquisas nos estudos do discurso para uma relação mais íntima entre a mídia e as análises que dela fluiriam na emergência de seus acontecimentos. Deixou sua caixa de ferramentas analíticas e com ela podemos ampliar o alcance de suas pesquisas ou mesmo, como talvez ele próprio, em oposição às ferramentas, preferisse dizer: "Mais tarde, os historiadores e outros especialistas poderiam dizer que tal ou tal livro foi tão útil quanto uma bomba, e tão belo quanto um fogo de artificio" (FOUCAULT, 2006a, p.267).

Nossa inquietação diante da narrativa filmada sobre os indígenas isolados foi justamente a forma como a produção se coloca ao lado de uma violenta hierarquia. São alguns pontos que precisamos destacar. Primeiro, o isolamento os coloca em estado imediato de guerra, pois eles estão em uma fronteira, que hora ou outra ameaça cruzar a tênue barreira do desconhecimento mútuo. Em segundo lugar, este tipo de contato quase sempre é trágico para os povos nativos e não faltam, em nossa história relatos de depopulação e genocídios sofridos por estas sociedades. Por fim, existe uma mazela cruel, invisível e mortífera neste tipo de contato, as doenças, que podem ser transmitidas, uma vez que estes sujeitos não tiveram seus corpos docilizados pela medicina e por isso não possuem defesas, anticorpos, contra doenças forasteiras.

É necessário observar o lugar de enunciação das pessoas que colocaram estas histórias filmadas em circulação, pois ele é bastante significativo e faz com que toda a história fique um pouco mais cinzenta. $\mathrm{O}$ vídeo que não quisemos analisar foi registrado pela Funai, uma instituição do Estado brasileiro responsável pelo governo dos povos indígenas, supostamente responsável por protegê-los. A outra entidade é uma instituição internacional ligada a uma igreja evangélica. Paradoxalmente, em caso de um conflito direto com aqueles indígenas isolados, seriam justamente estas instituições, igreja e estado, as primeiras linhas de "defesa" deste povo. Sabemos bem, no entanto, o preço a ser pago por esta proteção, "governo da alma", "governo do corpo" e "governo da terra". Por que, então, colocaram este vídeo em circulação na WEB?

Muitas sociedades indígenas vivem nas fronteiras culturais e históricas do Ocidente. A forma como reagem a este contato muitas vezes gera 
uma série de dificuldade com suas próprias tradições. Nestas fronteiras, a negociação com o futuro às vezes toma proporções dramáticas, pois produz uma sensação de não pertencimento, isto é, não pertencem nem a uma sociedade indígena, nem conseguem inserção no mundo ocidental. (NEVES, 2009, p.141)

Esta opção da não-imagem, se dá justamente, como uma das formas de crítica que podemos exercer. É preciso que nós repensemos até que ponto, tanto pesquisadores quanto jornalistas, tanto linguistas e antropólogos, quanto padres e pastores, não estão empreendo nas Terras Indígenas, e não só nelas, um "roubo de almas", por meio da imagem. Isso nos coloca em uma questão que devemos observar com muita atenção, e que certamente atinge a todos nós de uma forma ou de outra, são as mediações que nossas subjetividades negociam no interior da história a partir de acontecimentos discursivos e seus jogos de poder e saber nas mais diferentes mídias.

\subsection{Michel Foucault, um jornalista arqueólogo e sua atitude genealógica}

No meio de sua pirotecnia, que causava e continua produzindo tantas polêmicas, Michel Foucault anunciou, entre outras coisas, que a filosofia estava tramitando-se e debatendo-se com o jornalismo. Talvez, por esse motivo, ao ser questionado por um estudante se não era uma profeta, respondeu: "Eu sou um jornalista" (FOUCAULT, 2006b, p.267). E o que seria o trabalho de um jornalista, nesta perspectiva foucaultiana, se não fazer um diagnóstico do presente, causar pequenas explosões, que efetivamente ajudassem um indivíduo ou um grupo a não ser mais sujeito a uma espécie de poder? Por este motivo, os nossos trabalhos a partir dos estudos do discurso com Michel Foucault tomam cada vez mais o corpo na mídia e os discursos que dele são produzidos, como grandes objetos de análise. "O banal se analisará segundo a grelha eficaz, mas cinza da administração, do jornalismo e da ciência; exceto se for buscar seus esplendores um pouco mais longe disso, na literatura" (FOUCAULT, 2003, p.216). Então, em nossos recortes de pesquisas, selecionamos filmes institucionais, mas também detivemos o olhar na simplicidade de vídeos publicados nas redes sociais e mesmo no silêncio.

Daí a importância de uma atitude genealógica, ao analisarmos discursos que circulam nessas histórias filmadas. Devemos fazer um esforço para não nos colocarmos ao lado dos saberes maiores, inquisidores. Para não sermos instrumentos da sujeição dos saberes locais. Por isso, cabe ao arqueogenealogista contar ou interpretar uma história a partir das batalhas que surgem em torno do corpo dos sujeitos, através dos discursos que dele foram (re)produzidos, ou seja, sempre partiremos de uma materialidade para 
rarefazer os discursos que se inscrevem no corpo, nas nossas subjetividades, no teatro das verdades.

Como Foucault (2007) nos mostrou, o discurso está submetido por uma ordem. Existe um domínio do que é dito, e a emergência do que é dito é subordinada pelas condições históricas de enunciação. São curvas de enunciabilidade e visibilidade como nos disse Deleuze (1996). Este domínio das coisas ditas, ou seja, o arquivo é uma rede inteligível e, certamente, gigantesca de performances verbais e não verbais que se entrecruza descontinuamente no palco da história. Foucault (2008a, p.I ) nos diz: “O domínio das coisas ditas é o que se chama arquivo; o papel da arqueologia é analisá-lo". A partir disto, podemos pensar que é preciso de uma ordem do olhar. Alguma coisa dita, mostrada no meio desta rede imensa vai saltar sobre nossos olhos, e o que vai nos chamar atenção está materializado, tem uma forma, um corpo, é uma linguagem apreensível. Este é o primeiro ponto, o trabalho da arqueologia consiste em fazer uma análise que está no domínio do arquivo.

A arqueologia traz em sua empresa lugares outros, e uma relação com os saberes institucionalizados, com regras e procedimentos científicos. Segundo Foucault (2008a, p. 203), a arqueologia "tem, inicialmente, relação com ciências que se constituem e estabelecem suas normas no saber arqueologicamente descrito e que são para ela ciências-objetos tanto quanto já o foram a anatomia patológica, a filologia, a economia política, a biologia”. É possível fazer ou contar uma história pelos vencedores, ou ainda usar a ciência para repudiar saberes locais e dominá-los. Buscar nestas materialidades, instrumentos de repressão e lógicas aparentes; cálculos atômicos criam eletricidade ou bombas genocidas. Não é este o objetivo de uma pesquisa arqueologicamente dirigida, segundo Foucault, "trata-se de operar um descentramento que não permite privilégio a nenhum centro" (FOUCAULT, 2008a, p. 213). A arqueologia nos mune de ferramentas para questionar estes saberes ditos qualificados, descentralizá-los e analisar suas diferenças. É o método pelo qual podemos fazer surgir as discursividades.

Já a genealogia é a tática de reativação de saberes locais. É uma atitude que é tomada a partir do método. É o pensar diferente diante da descentralização do saber. É observar o jogo de relações de poder que se materializam em nossos corpos e ir além do diagnóstico. É mostrar possibilidades de fuga, táticas de resistência. A genealogia seria, portanto, a "reativação dos saberes locais - menores, diria talvez Deleuze - contra a hierarquização científica do conhecimento e seus efeitos intrínsecos de poder" (FOUCAULT, 2007, p.172). Esta virada a uma nova vontade é a busca destas 
genealogias. É olhar nas lesões de um arquivo, para parte encoberta da rede de sentidos em um determinado recorte que nossos olhos traçam, por meio dos confrontos e dos embates que se dão sobre os sujeitos de forma belicosa. É a partir de uma análise arqueológica que vai emergir a tática genealógica.

Para definição de sua metodologia, Foucault vai explicitar algumas precauções. Segundo ele, a pesquisa deve ser orientada para a "dominação, os operadores materiais, as formas de sujeição, os usos e as conexões da sujeição pelos sistemas locais e os dispositivos estratégicos" (FOUCAULT, 2007, p. 103), ou seja, é preciso usar estratégias, fugir do centro dos acontecimentos e procurar os indícios na margem. Vale destacar, que ele não descarta os "operadores materiais". Em oposição, destaca também que a pesquisa sobre o poder não deve ser orientada a partir de um edifício jurídico da soberania ou mesmos de aparelhos de Estado e das ideologias que o acompanham.

Foucault (2007) nos explica que o poder não deve ser estudado no modelo de um Leviatã ${ }^{4}$, ou seja, delineado por uma instituição estatal ou mesmo por uma soberania jurídica. É preciso que o estudo sobre o poder se dê a partir das táticas e das estratégias de dominação. Desta forma, ele nos apresenta, em sua obra, um esboço de sua metodologia. Podemos fazer algumas considerações: a realidade para ele se apresenta rodeada por uma historicidade belicosa que funciona a partir de relações de poder; os poderes são circulares e acontecem a partir das produções de verdades, por onde os sujeitos exercem e se submetem ao poder; o corpo é uma realidade biopolítica; uma analítica do poder não se concentra nas grandes estruturas, nos aparelhos do Estado, mas nas margens, a partir das estratégias de dominação e mais ainda; - estas pesquisas teriam por obsessão final uma ontologia crítica do presente. Em seu texto $O$ que são as Luzes? Michel Foucault apresenta esta ideia da crítica do presente, assim como situa este procedimento:

Aquilo que, nós o vemos, traz como conseqüência que a crítica vai se exercer não mais na pesquisa das estruturas formais que têm valor universal, mas como pesquisa histórica através dos acontecimentos que nos levaram a nos constituir e a nos reconhecer como sujeitos do que fazemos, pensamos, dizemos. Nesse sentido, essa crítica não é transcendental e não tem por finalidade tornar possível uma metafísica: ela é genealógica em sua finalidade e arqueológica em seu método. Arqueológica - e não transcendental - no sentido de que ela não procurará depreender as estruturas universais de qualquer conhecimento

\footnotetext{
${ }^{4}$ O Leviatã, obra de Tomas Hobbes publicado em 1651. A refere-se ao Estado forte e soberano que dominaria os sujeitos pelo poder punitivo. O Leviatã é um ser mitológico considerado o mais e mais poderoso dos monstros marinhos, no livro, Hobbes o associa ao governo.
} 
ou de qualquer ação moral possível; mas tratar tanto os discursos que articulam o que pensamos, dizemos e fazemos como os acontecimentos históricos. E essa crítica será genealógica no sentido de que ela não deduzirá da forma do que somos o que para nós é impossível fazer ou conhecer; mas ela deduzirá da contingência que nos fez ser o que somos a possibilidade de não mais ser, fazer ou pensar o que somos, fazemos ou pensamos. (FOUCAULT, 2008b, p.347/348)

Rosário Gregolin, ao pensar a relação de Michel Foucault com esta ontologia crítica, com este diagnóstico da atualidade vai nos dizer: "Esse diagnóstico do presente não se contenta em caracterizar o que somos hoje, mas também tem por função apontar como o que é poderia não mais ser o que é. Como o que é poderia ser diferente" (GREGOLIN, 2016, p.113). Então, ao pensamos nesta pergunta: "quem somos nós hoje?" E ainda "como poderíamos ser diferentes? " Colocamo-nos neste lugar de crítica de nós mesmos, para reativar em nossos corpos saberes que foram dominados, não apenas pelos grandes poderes do Estado, mas também pelas micro lutas, dos pequenos embates cotidianos.

\section{O corpo heterotópico submergido}

As heterotopias são lugares absolutamente outros, reservados em muitos casos aos infames, daí o nascimento das clínicas para segregar os doentes, dos hospícios para os loucos, das prisões para os criminosos. Mas há também lugares de passagem, definidos pelo tempo. Para Foucault (2005), esses espaços existem possivelmente em todas as sociedades e se encontrariam numa área localizável, embora subvertida, subversiva, subterrânea. Agora, no entanto, nossos corpos atravessam pela WEB, lugares e tempos que outrora eram inatingíveis e nos permitem novas experiências com o passado distante. Quadros vivos se mexem e dão vida às nossas cidades do passado. Podemos ouvir a voz do filósofo do século passado, olhar seus olhos refletidos em nossos óculos pelo écran neon da tela do computador. Podemos falar com o parente distante que jamais veríamos novamente. Aquele vídeo que arruinou a vida do casal salta de celular para celular e disputa nossa atenção entre as futilidades do dia-dia e a delação premiada do político e do empreiteiro, a malvadeza do presidente, a Fake News do fundamentalista.

Navegamos submersos em um estranho mar sem água, cheio de aventuras e desventuras, que vai emergir mais ou menos na metade do século XX e consolidar sua inundação, em nossa sociedade, no começo deste século. Apesar deste recém-nascido mar de bits ser respirável, é turvo, por vezes sufocante. Nas ilhas, as sereias cantam e 
levam os marinheiros ao fundo mais obscuro. Krakens e hackers estão sempre à espreita. Piratas roubam o ouro guardado nos bancos e o que era número, de repente, vira papel e moeda. Corsários aventureiros oferecem todos os tipos de viagem e mercadorias. Há mais livros e escrituras que a biblioteca de Alexandria ou que qualquer outra jamais conseguiu reunir ou queimar. Há mais filmes do que qualquer cinema pôde exibir, nem mesmo todos eles juntos poderiam tanto.

Se o navio tem esse papel de metáfora primordial até o século XX, proponho pensar a WEB como a heterotopia por excelência do século XXI. Nesse espaço virtual cruzam-se todo tipo de outros espaços, consensuais e conflitantes; acolhem-se todo tipo de enunciados e de formas de visibilidade numa cartografia em que se misturam permissividade e controle de forma ambígua; o seu funcionamento tem em sua base o contínuo movimento do dito e do não dito. Navegamos por esse labirinto e a velha metáfora da navegação convive com outras formas de experimentar lugares nunca dantes navegados (GREGOLIN, 2015a, p.197).

Existem mais línguas tagarelando nesse lugar do que havia em Babilônia. Mais pessoas navegam neste mar do que em todos os sete mares juntos. Aliás, cidade alguma atende a uma população tão grande, nem mesmo as megalópoles do mundo atual. $\mathrm{O}$ mais curioso é que, ao mesmo tempo, ninguém realmente está lá. Esse mar não é tateável, não existe no mesmo plano que nós. São espelhos interativos, mas que podem efetivamente nos ferir, causar dores, despertar paixões, sonhos e medos. Esses espaços, embora pareçam autônomos, não preexistem ao corpo e tão pouco fazem sentido sem ele. Estão lá para servi-lo e controlá-lo, para curá-lo ou para matá-lo. Lugar de liberdade e repressão obsessivas, cheio de fugas e vigilâncias excessivas. A utopia efetivamente realizada para nossa alegria e para o nosso ódio, para a dor e o amor.

Certamente que em seus estudos, principalmente em "As Palavras e as Coisas" (1969), Foucault nos deixa claro que as coisas não preexistem às palavras, mas fazemos a pergunta: não seria o corpo o alvo de todas as palavras, de todos os gestos, todas as músicas, todas as casas, hospitais, carros, bordeis, navios, de todos os livros, filmes e fotos, de todos os sentidos, o lugar do que é inventado? O corpo, lugar do sujeito. O corpo, inevitável identidade do ser. O corpo, o próprio discurso acontecido. Repartição impiedosa de nós.

Segundo Foucault (2013), na obra de Homero, a palavra grega que significa corpo só aparece para designar cadáver. Para o historiador grego, o cadáver e o espelho nos ensinam que temos um corpo, com forma específica e um lugar no espaço. Graças a eles, o corpo não é uma pura e simples utopia, pois a imagem do espelho está num 
espaço inacessível, onde jamais poderemos estar juntos de nosso cadáver, já que eles estão num invencível outro lugar ${ }^{5}$.

O corpo é finitude, topia, jaula e talvez ele seja a maior ironia que experimentamos atualmente. Provavelmente, nunca ocupamos tantos lugares fora do corpo e nunca fomos tão esticados para fora de nós mesmos como na época atual. Hoje, boa parte de nós, em nossa sociedade tem, no mínimo, uma, e possivelmente várias imagens icônicas, que contam nossa história, tanto quanto sujeito, como sociedade.

Temos verdadeiros diários cheios de nós nas redes sociais, álbuns de famílias, registros em bancos, escolas, hospitais, atestado militar, certidão de nascimento, casamento, divórcio. Uma infinidade de documentos com fotos: carteira de identidade, trabalho, motorista, passaporte, que travam nossas vidas sem o seu auxilio. É como se na época atual, as pessoas não prescindissem, também as imagens. Como no caso de bebês, que já possuem uma foto e uma filmagem ainda na barriga de suas mães, antes mesmo de possuírem um nome.

Nada disso, porém, nos livra do corpo. Nunca poderemos sentir nada por de fora dele, nunca amaremos de outro lugar que não seja do nosso próprio corpo. Podemos produzir verdades, sobre nós e sobre os outros, produções de uma verdade, relação de poder que perpassa o corpo e que nunca pode ser sentida fora dele e, ao mesmo tempo, nossos corpos não existem sem elas. Não seriamos nada sem as verdades que nos produzem. Se somos o que somos é por causa dos discursos que nos atravessam e nos levam para além de nossos corpos. Sem os discursos, somos apenas cadáver enterrado num silêncio absoluto e solitário e só por meio dele podemos recuar a corrosiva flecha do tempo.

O corpo: superfície de inscrição dos acontecimentos (enquanto que a linguagem os marca e as idéias os dissolvem), lugar de dissociação do Eu (que supõe a quimera de uma unidade substancial), volume em perpétua pulverização. A genealogia, como análise da proveniência, está, portanto, no ponto de articulação do corpo com a história. Ela deve mostrar o corpo inteiramente marcado de história e a história arruinando o corpo. (FOUCAULT, 2007, p.15)

\footnotetext{
${ }^{5}$ Foucault também concebe o nosso reflexo no espelho como uma heterotopia: "O espelho, afinal, é uma utopia, pois é um lugar sem lugar [...] o espelho funciona como uma heterotopia no sentido em que ele torna esse lugar que ocupo, no momento em que me olho no espelho ao mesmo tempo absolutamente real, em relação com o todo o espaço que o envolve, e absolutamente irreal, já que ela é obrigada, para ser percebida, a passar por aquele ponto virtual que está lá longe[...] (FOUCAULT, 2005,p.235 Outros espaços).
} 
Segundo Foucault (2007), quando estudarmos a história, não encontraremos uma alma imortal, mas sim várias almas e todas elas terrivelmente mortais. É para o corpo dos vivos que os discursos existem. O enunciado é infinitamente repetível, e o acontecimento é imprevisivelmente escorregadio em sua emergência. Para nossa desventura, não encontraremos a metafisica na análise do discurso sob as lentes foucaultianas, apenas as aventuras, batalhas, lutas, dores e prazeres de uma microfísica mundana, uma analítica do poder de genealogias fragmentadas.

\section{A Pluralidade das almas descontinuas: o sujeito reproduzido no mar de bits}

"Filmou isso aí? Esse bando de índio ladrão e ainda com flecha e com arco?" - Estas palavras são ditas no momento em que um carro passa por dois indígenas, na beira de uma estrada, no Estado do Mato Grosso. O fotograma e este enunciado verbal foram retirados do vídeo Índios no $M T$, entre Juína e Joara cobram pedágio armados de paus, pedras, arcos $e$ flechas. Ai de você se não pagar...,

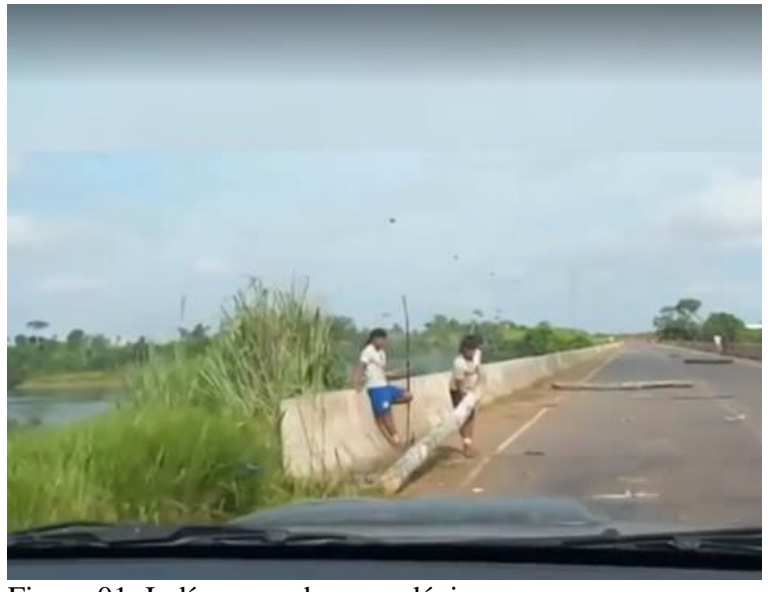

Figura 01: Indígenas cobram pedágio Disponível

em:https://www.facebook.com/PatataPatriota/videos/17305 01170597887/?hc_ref=NEWSFEED

filmado em um celular, publicado no Facebook, compartilhado e reproduzido milhares de vezes. A partir deles, os discursos proliferam lâminas por entre o painel, o retrovisor e os troncos das árvores espalhados na ponte. O carro parece ir, ameaçadoramente, de encontro ao indígena, cuja expressão corporal nos dá a impressão de que será capaz de erguer o tronco contra o carro. Cenas de um conflito latente, agonias de imagens belicosas. De calção azul e camisa branca, o outro indígena apenas observa, com as mãos recostadas nas muretas e o arco erguido ao lado de uma de suas pernas.

Um acordo foi selado. O motorista e seu passageiro negociam a passagem por cem reais, nem mais, nem menos. Um pedágio foi quitado. O cessar fogo, por hora foi mantido. Não se sabe a volta. O passageiro enraivecido declarara ao vigia indígena: "Tenho que trabalhar dois dias pra ganhar cem reais!!" E o motorista questiona: "Pra que isso rapaz? Precisa disso tudo?" O indígena apenas sentencia ao balançar a cabeça: "Sim..." 
Não havia grandes guichês, não havia placas de aviso de que se ultrapassassem sem pagar o pedágio seriam acrescidos de multa, pontos na carteira. Tampouco houve a necessidade de moedas para facilitar o troco. Nada de miudezas, apenas a nota azul de, até então, maior valor no Brasil, o dinheiro que possui, ironicamente o peixe impresso nas costas. Uma ponte, um lugar de passagem. Erguida, provavelmente, nas fronteiras de uma Terra indígena, esta ponte, torna-se uma artéria exposta no espaço. Que épocas atravessam o horizonte dessa ponte? Queremos mesmo saber, apreender e provavelmente nos cortar? Os diferentes tempos saltam nos espaços e podemos ver um discurso, um acontecimento, ligar-se, dar choque.

Como nos diz Foucault (2006b, p.34): “O discurso, como se sabe, tem o poder de deter a flecha já lançada em um recuo do tempo que é seu espaço próprio”. O tempo recua sobre nós e podemos ver a política como a guerra prolongada, a continuação das batalhas que jamais se encerrariam nas heterocronias capturadas por essa ponte. É como se apenas um armistício fosse assinado, reativado a cada nova ocupação, a cada nova passagem.

Essas terras são pontos sensíveis, frágeis, delicados e muito combativos de nossa sociedade. Fronteiras de guerras, lugares que se retalham uns sobre os outros por épocas diferentes, mas simultaneamente na emergência de seu acontecimento. Esta falsa paz se dá por vários motivos. Precisaríamos ver que cada povo indígena tem uma narrativa, uma história peculiar, embora muitos deles estejam unidos por suas mazelas: demarcações de terra, doenças e atentados são alguns dos mais visíveis problemas comuns desses povos. Novamente, cada um seguindo sua própria diversidade e adversidade.

Como vemos no caso deste vídeo, existe uma estrada, que aparentemente corta, ou pelo menos está próxima a uma Terra Indígena. Uma estrada ao lado de áreas de mata é sempre um chamado para o fogo. Como ocorre em boa parte deste tipo de produção, não possuímos muitas informações. Não sabemos, por meio do dela, se ali, é realmente uma aldeia, a qual povo estes indígenas pertencem. São retratados apenas como "índios". A seguir, trouxemos um fragmento, recortes dos comentários veiculados junto ao vídeo. 
Lutitus canbada de ladrões índios tem que anda e nu não com uma camisa gola pólo um boné e td mais isso ¡ão raça desgraçada ladra

Jurtir - Responder - (1) 1. 18 de abril às 11:07 - Editado

num ferreira Pegar uma metralhadora com uns mil tiros por segundo e metralhar todos vagabundos bandidos. 'urtir - Responder - $3 \cdot 16$ de abril às 18:43

Figura 02: Comentários do vídeo

Disponível em: https://www.facebook.com/PatataPatriota/videos/1730501170597887/?hc_ref=NEWSFEED. Acessado em 21/04/2017

Escolhemos estes dois comentários entre os milhares que estavam entrincheirados nas bordas deste vídeo, porque eles revelam muito sobre algumas questões que gostaríamos de levantar. A primeira delas diz respeito ao estereótipo que se criou a partir da reprodutibilidade excessiva de determinados discursos. Um tipo de objetivação sobre o sujeito indígena. Para ser "índio" é preciso estar despido de roupas, estar com grafismos, não possuir nada que possa ser associado ao não indígena como: carros, aparelhos domésticos, celulares, bonés e até mesmo óculos. Aqueles que fogem desta regra são constantemente reprovados, perdem o direito a esta "identidade". Não podemos esquecer, por fim, que estes sujeitos só podem viver desta maneira nas Terras Indígenas, nunca na cidade, afinal, é proibido andar sem roupas pelas ruas do Brasil.

Uma prática objetivadora bastante reproduzida é o discurso da oposição entre o trabalho e os povos indígenas. Associa-se a esses povos o ócio, a exploração e a ocupação desnecessária da terra. Estes discursos são bem cristalizados em nossa cultura e reforçam a ideia de que os indígenas têm "vida boa", moram no paraíso, não fazem nada a não ser dançar e ficarem nus em suas redes o dia inteiro, "num eterno domingo". Podemos ver uma atualização deste discurso, tanto nos enunciados dos passageiros do carro, como nos comentários em que os indígenas são chamados de "vagabundos", e por isso deveriam ser metralhados. Construir uma identidade indígena associada ao ócio foi um dos instrumentos mais potentes do sistema colonial para justificar a colonização e hoje a colonialidade do poder atualiza estes discursos que podemos observar no vídeo e nos comentários.

Verdades essas que tiveram sua emergência no período colonial, como nos mostra Neves (2009), mas que atualmente são reforçadas por uma série de discursos veiculados majoritariamente e preferencialmente nas mídias. Nas mídias digitais encontramos uma forma menos editada, menos polida e mais escancarada desses discursos. 


\subsection{Novas emergências no Rio das Mortes}

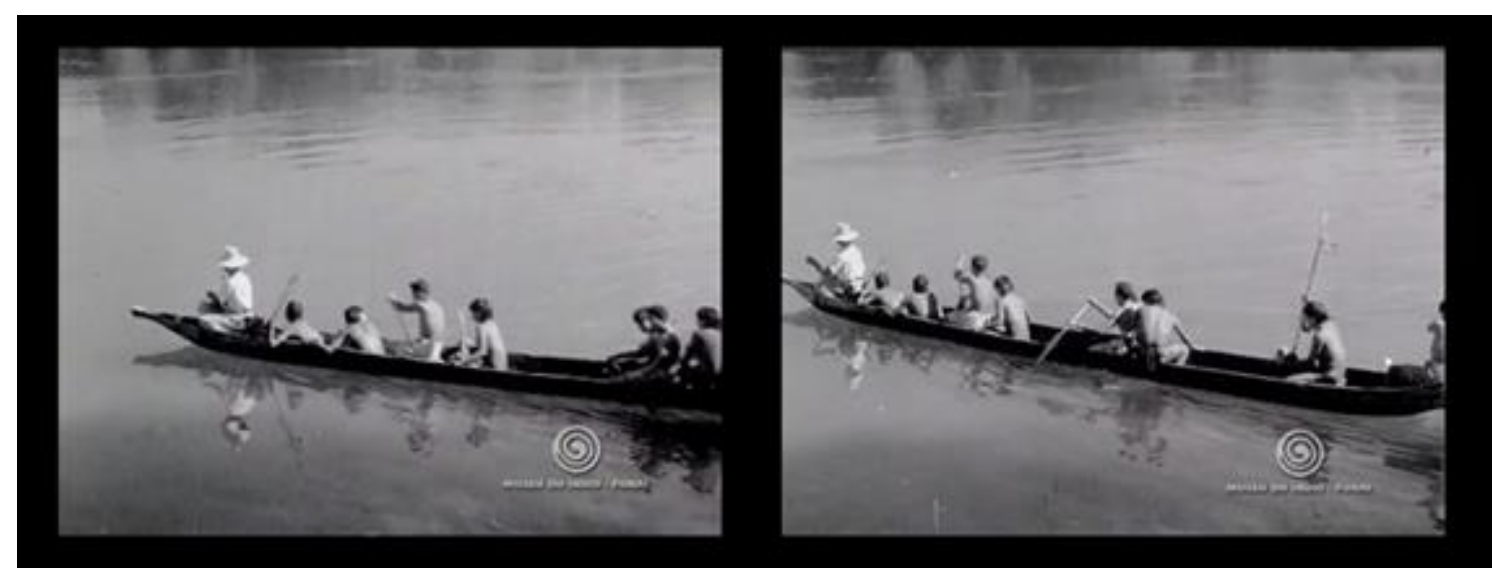

Figura 03: As canoas do SPI/RS

Disponível em https://www.youtube.com/watch?v=kOPurJGndnY: Acessado em 02/05/2017

A história como uma trama que entrecruza os tempos vai nos revelar ligações discursivas através de acontecimentos em que os discursos vão se unir e se repelir uns aos outros. A figura acima é uma compilação de fotogramas do filme "Guarita. Serviço de Proteção aos Índios - SPI/RS” (1940). Este breve relato sobre a pacificação dos Xavante trata de uma ação do SPI junto aos Xavante e Kaingang. O filme sobrepuja um clima totalmente ufanista com uma narração eloquente e uma trilha instrumental marchada. Nestas duas primeiras imagens podemos ver um representante do SIP de roupas claras na vanguarda de uma canoa guiada pelos Xavante. Este vídeo faz parte de uma série de propagandas que o Estado $\mathrm{Novo}^{6}$ produziu para reafirmar sua "Marcha para o Oeste", um programa de colonização e expansão capitalistas que rasgou as terras brasileiras. O indigenista seria o guia dos indígenas ao novo tempo, à modernidade. Abaixo selecionamos alguns trechos do texto da narração.

O Brasil é um imenso país que cada dia tem mais uma surpresa a apresentar. Como o fato esquecido que deve ser lembrado, como o lendário Rio das Mortes. Suas águas turvas impediram muitas vezes as avançadas dos bandeirantes, que pretendiam aumentar o território brasileiro. [...] Os índios foram outros obstáculos, como os Xavantes que hoje se confraternizam com o Serviço de Proteção aos Índios e que vão sendo aos poucos preparados para ser úteis a si mesmos e a coletividade. [...] A atitude pacífica e acolhedora dos homens do Serviço de Proteção aos Índios, faz crescer a confiança dos Xavantes na civilização dos brancos (GUARITA, 1940).

O Rio das Mortes banha o estado do Matogrosso e é o lugar por onde vemos a canoa flutuar. Estes enunciados que transcrevemos acima estão na abertura do vídeo e

\footnotetext{
${ }^{6}$ Também conhecido como Era Vargas ou Terceira República compreende um período entre 1937 e 1946 em que Getúlio Vargas governou o Brasil.
} 
nos mostram histórias desta colonização que não se findou. A memória dos bandeirantes é retomada e atualizada na figura do indigenista em contraste com o corpo despido dos Xavante. O rio recebeu este nome dos Xavante, justamente pelas batalhas contra os bandeirantes que ocorreram no curso de suas águas. Os homens do SIP, no entanto, aparentemente são bem diferentes dos bandeirantes e eles não estariam empreendendo uma conquista, mas sim uma pacificação. Com suas roupas brancas, estes indigenistas procuravam não mais o confronto e sim a assimilação destes povos à coletividade nacional, mas com fraternidade, para que assim pudessem confiar na "civilização dos brancos". Contudo, sabemos que, independentemente da denominação ou das intenções daqueles que ultrapassaram esta fronteira de contato, ele sempre resultou em uma grande depopulação das sociedades indígenas.

Segundo informações recolhidas no site do Programa Povos Indígenas no Brasil, os Xavante são um povo Jê que habitam várias Terras Indígenas no estado do Matogrosso. Foi por meio desta campanha, empreendida pelo SPI, que eles se tornaram mais "conhecidos" no país. Há, no entanto, uma perspectiva da pacificação enunciada pela maioria dos Xavantes sobre este processo sistemático de contato bem diferente da versão oficial. Na versão deles, os "brancos" é que deveriam ser "pacificados". Como não puderam impedir, o contato sistemático causou uma série de mudanças nas práticas tradicionais ${ }^{7}$ deste povo.

Irmãos dos Xavantes em sangue e bravura, os índios Kaingang, já bastante civilizados, são um exemplo marcante da utilidade de seus trabalhos. [...] Os Kaingang formam uma tribo que vivia do aproveitamento do solo regado pelo rio guarita. Hoje, com suas terras demarcadas eles ainda utilizam o solo como fonte de maior produção, dedicando-se com interesse à agricultura. [...] Esses índios viviam antigamente como os Xavantes, mas no momento contribuem ativamente com uma boa quantidade de trigo, cobrindo seus vastos campos e dignificando o indígena brasileiro (GUARITA, 1940).

\footnotetext{
${ }^{7}$ Os agentes do contato e as maneiras como este se deu influenciaram os grupos xavante de distintos modos. Crenças e práticas religiosas, bem como algumas instituições sociais e práticas cerimoniais foram afetadas, em especial entre aqueles que travaram contato com missionários, sejam eles católicos ou evangélicos. Apesar desses impactos, a Cultura Xavante continua a se manifestar com extrema vitalidade, sendo retransmitida de geração em geração através da língua e de inúmeros mecanismos sociais, cosmológicos e cerimoniais. Para além de algumas diferenças notadas pelos etnógrafos entre os diversos grupos locais xavante por conta das referidas experiências distintas de contato, a língua comum, os padrões de organização social e instituições, as práticas cerimoniais e a cosmologia definem os Xavante como uma totalidade social. Suas comunidades, contudo, são politicamente autônomas, ainda que às vezes se unam para atingir objetivos comuns. In https://pib.socioambiental.org/pt/povo/xavante
} 


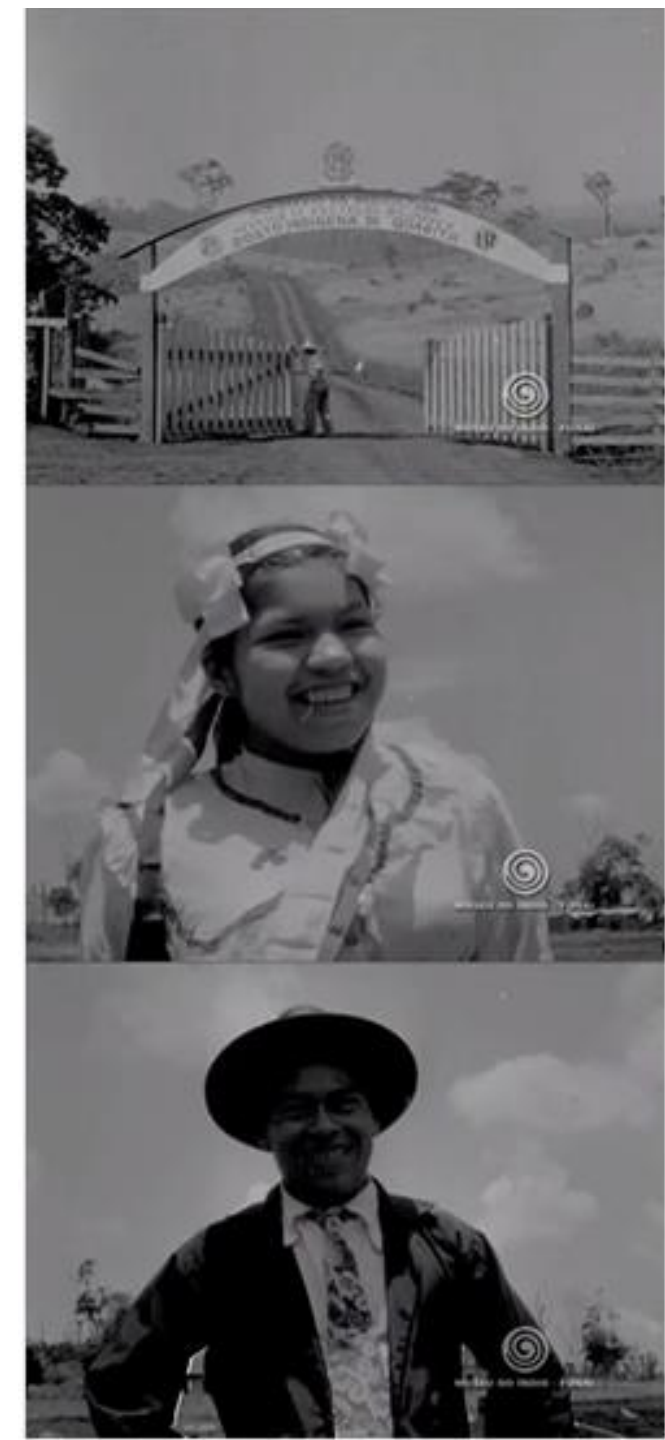

Figura05: Trabalhadores Kaingang Disponível em:

https://www.youtube.com/watch?v=kOPurJGndnY: Acessado em 02/05/2017

Esta outra compilação de fotogramas ao lado e os trechos da narração que selecionamos acima continuam a construir a ideia de "pacificação", por meio dos Kaingang, que a esta altura já haviam sido "civilizados". O vídeo então, nos leva para Terra Indígena Kaigang que fica nas margens do Rio Guarita no estado do Rio Grande do Sul. Podemos notar o close da câmera nos perfis dos rostos sorridentes da mulher e do homem Kaingang e as roupas e os adereços usados como estratégia para demostrar a "civilidade" dos indígenas.

Os Kaingang da Terra Indígena Guarita, assim como os Xavante são um povo de língua e tradição Jê. Segundo informações do Portal Kaingang, tiveram suas terras demarcas, inicialmente na primeira década do século XX, mas elas foram (re)demarcadas na década de 90 do mesmo século.

O trabalho, as roupas e o bem da coletividade nacional ressignificam o corpo indígena e lhes conferem "dignidade". A partir destes elementos, os jogos de poder vão duelar entre os corpos indígenas neste vídeo e estabelecer a oposição Xavante selvagens e despidos versus Kaingang civilizados e vestidos. Nesta história filmada, o caminho dos Kaingang deve ser seguido, para que assim os Xavante também possam "glorificar" o indígena brasileiro. Há ainda uma outra condição singular entre estes dois povos: os Xavante vivem no Matogrosso e os Kaingang deste vídeo, no Rio Grade do Sul, uma região muito mais fria, o que nos leva a crer que provavelmente, antes mesmo deste contato com a sociedade envolvente, eles já usavam roupas.

A ideia de que é o trabalho que "dignifica o homem", e de que os Xavante iriam finalmente servir à coletividade, além deles mesmos, revela um tempo, em que, a norma

\footnotetext{
${ }^{8} \mathrm{http} / / /$ www.portalkaingang.org/index_guarita.htm
} 
vigente era a assimilação. Os indígenas dessa época teriam de ser assimilados, assim como todas as práticas locais, que se opunham ao progresso. Isto claro, fundamentado em um projeto do governo brasileiro para construção de uma identidade nacional. Por outro lado, os indígenas da atualidade, uma vez que não são mais puros, deveriam trabalhar e deixar o "ócio" de lado. Desde o início da invasão deste continente, o discurso eurocêntrico/escravocrata sobre o trabalho encontrou muita resistência entre os povos indígenas. No Ocidente, o trabalho, mesmo com todas suas implicações com a exploração capitalista, se impõe como se fosse uma condição biológica para a existência humana.

Traçando um paralelo entre os dois filmes, a docilização e a urbanização do corpo são apresentadas de formas diferentes. Enquanto no primeiro, a partir das tecnologias de poder estabelecidas pelo governo do SPI, os indígenas têm retirado de si a autenticidade de sua identidade, a segunda produção já subverte está ordem e toma o caminho oposto. $\mathrm{O}$ vídeo postado no Facebook enquadra os indígenas com o intuito da galhofa e da vingança por não atenderem ao estereótipo, já o filme produzido pelo SPI na década de 1940 exalta sua atuação, ao mostrar como será a ascensão Xavante: de selvagens a quase "brancos civilizados", ajudantes do país, fiadores da coletividade.

Olhamos para estes dois vídeos e vimos neles algumas possíveis recorrências, sobretudo o desejo de governar os povos indígenas e a implicação da nudez e do trabalho, mas paramos nossos olhos na dispersão, que veste e despe o indígena para tentar acompanhar as descontinuidades da história. As relações de poder que atravessam os discursos nos mostram como a história se adapta às diferentes necessidades, não através da apreensão dos sentidos, mas a partir das lutas que se inscrevem no corpo dos sujeitos. Estes discursos nos mostram batalhas concretas, éticas, estéticas e biopolíticas das subjetividades que se inscrevem em nossos corpos, nas identidades que irrompem de nossas almas mortais.

\section{Considerações finais}

Perceber este sistema complexo de elementos múltiplos nas identidades das sociedades indígenas, a partir dos discursos colocados em circulação pelas histórias filmadas torna-se, então, um desafio em meio à camisa de força dos estereótipos a que estas sociedades são envoltas. Muitos discursos são fixados nestas relações de poder baseadas no colonialismo e sua negação; o "indígena selvagem”, ou então, o "bom selvagem" estabelecido pela literatura romântica, o indígena antropofágico e até mesmo 
o perigoso discurso de homogeneização e objetivação histórica que carrega o ser indígena. Pelo contrário, há uma pluralidade, não apenas de sociedades, mas no próprio sujeito, no próprio corpo.

A história, genealogicamente dirigida, não tem por fim reencontrar as raízes de nossa identidade, mas ao contrário, se obstinar em dissipá-la; ela não pretende demarcar o território único de onde nós viemos, essa primeira pátria a qual os metafísicos prometem que nós retornaremos; ela pretende fazer aparecer todas as descontinuidades que nos atravessam (FOUCAULT, 2007, p. 36).

Nossa pesquisa com os povos indígenas, nesta perspectiva da história genealogicamente dirigida, não procurou achar a raiz de uma identidade pura e estereotipada de um "índio". Ao contrário, procuramos dissipar estas identidades em meio à pluralidade e às descontinuidades históricas. Existe uma rede de memória na história das subjetividades das sociedades indígenas construída, em boa parte, através da reprodutibilidade dos filmes, documentários, reportagens. Estas materialidades criam uma rede de memória nas imagens e nos sons que ecoam pela história e atualizam as batalhas pela nossa subjetividade. Sem perder de vista que "nada é mais material, nada é mais físico, mais corporal que o exercício do poder" (FOUCAULT, 2007, p.84).

Neste sentido, as narrativas Yanomami sobre as câmeras e as almas, nos alertam sobre o papel que a imagem, seja como fotografia ou vídeo, ocupa nas lutas, na política e na ética em uma sociedade como a nossa. Estes discursos tomam contorno no corpo dos sujeitos, e aí percebemos de que forma a linguagem tem seus desdobramentos físicos e muitos mais do que produzir sentidos, produz lutas, embates, faz vestir roupas, despir grafismos. Estes acontecimentos em vídeo nos colocam imediatamente em uma rede da história, e forçosamente nos conduzem desornados uns aos outros, como imãs que se atraem e se repelem. Os discursos são como a ponte heterotópica que atravessa os diferentes tempos e faz ver, reativada, atualiza e atravessa todas as batalhas.

Quando ligamos através do discurso sobre a questão do trabalho, os Kaingang e os Xavante do século passado à indígenas do século XXI expostos nas redes sociais como "inimigos" da coletividade nacional, apreendemos um confronto que revela como os discursos usam de estratégias diferentes para fazer funcionar o poder sobre os corpos e sobre as "almas que foram roubadas pelas câmeras".

\section{Referências}

DELEUZE, G. O que é um dispositivo? In: O mistério de Ariana. Lisboa: Vega/Passagens, 1996, p. 83-96. 
FOUCAULT, Michel. A Microfísica do Poder. São Paulo: Graal, 2007.

A Ordem do Discurso. São Paulo: Edições Loyola, 2000.

. A arqueologia do Saber. Rio de Janeiro: Forense Universitária, 2008a.

A vida dos homens infames In: Ditos e escritos IV: Estratégia, Poder-Saber. Rio de Janeiro: Forense universitária, 2003.

O corpo utópico, As heterotopias, São Paulo: N-1 Edições, 2013.

Outros espaços. In: Estética: Literatura e Pintura, Música e Cinema. Coleção

Ditos \& Escritos III. Rio de Janeiro: Forense Universitária, 2005.

O Sujeito e o Poder. In: RABINOV, Paul; DREYFUS, H. Michel Foucault: Uma Trajetória Filosófica - para além do estruturalismo e da hermenêutica. Rio de Janeiro: Forense Universitária, 1995.

O que são as Luzes. In: Arqueologia das ciências e história dos sistemas de pensamento. Coleção Ditos \& Escritos, vol. II. Rio de Janeiro: Forense Universitária, 2008 b.

Diálogo sobre o poder. In: Estratégias, Poder-Saber. Coleção Ditos \& Escritos IV. Rio de Janeiro: Forense Universitária, 2006a.

A Linguagem ao Infinito. Estética: Literatura e Pintura, Música e Cinema. Coleção Ditos \& Escritos III. Rio de Janeiro: Forense Universitária, 2006 b.

Em defesa da sociedade. Trad. M. E. Galvão. São Paulo: Martins fontes, 2005.

História da loucura na idade clássica. Trad. J. T. Coelho Neto. São Paulo: Perspectiva, 2005.

As Palavras e as Coisas. Uma arqueologia das ciências humanas. Martins Fontes. São Paulo, 2000

GREGOLIN, M. R. F. V. Análise do Discurso e mídia: a reprodução das identidades. Revista Comunicação, Mídia e Consumo, São Paulo, Vol. 4, No11, 2007.

Identidade: objeto ainda não identificado? Estudos da Língua(gem) (Impresso), v. 04, p. 23-36, 2008.

Discursos e imagens do corpo: heterotopias da (in)visibilidade na Web. In: FLORES, G.; NECKEL, N.; GALLO, S... (Org.). Análise de discurso em rede: cultura e mídia. 1ed.Campinas: Pontes, 2015.

Michel Foucault: uma teoria crítica que entrelaça o discurso, a verdade e a subjetividade. In: FERREIRA, Ruberval; RAJAGOPALAN, Kanavillil. (Org.). Um Mapa da Crítica nos Estudos da Linguagem e do Discurso. 1ed.Campinas - SP: Pontes, 2016, v. 1, p. 115-142.

NEVES, Ivânia. Tese de doutorado: A invenção do índio e as narrativas orais Tupi / Ivânia dos Santos Neves. - Unicamp. Campinas, SP: [s.n.], 2009.

NEVES-CORREAA, Maurício. Tese de doutorado: Heterotopias no país do milagre: os corpos indígenas e as histórias filmadas. Unesp. Araraquara, SP, 2018.

YANOMAMI, Davi Kopenawa. Entrevista concedia ao programa Rodada viva da TV Cultura Paulista, $1998 . \quad$ Disponível em: 
http://www.rodaviva.fapesp.br/materia/42/entrevistados/davi_yanomami_1998.htm. Acessado em 13 de abril de 2017.

\section{Histórias filmadas}

" Índios no MT, entre Juína e Juara cobram pedágio armados de paus, pedras, $\operatorname{arcos} \mathrm{e}$ flechas. $\mathrm{Ai}$ de você se não pagar.... Disponível em: $<$ https://www.facebook.com/PatataPatriota/videos/1730501170597887/?hc_ref=NE WSFEED>. Acessado em: 10 abr. 2017.

Guarira, (1940), 2016 (6:50 min), Museu do Índio Botafogo. Disponível em:< https://www.youtube.com/watch?v=kOPurJGndnY>. Acessado em :2 mai.2017 